\title{
Pendekatan Biophilic untuk Meningkatkan Kualitas Ruang pada Perkantoran Vertikal
}

\author{
Kartika Rahmasari dan Endy Yudho Prasetyo \\ Departemen Arsitektur, Fakultas Teknik Sipil dan Perencanaan, Institut Teknologi Sepuluh Nopember (ITS) \\ e-mail: end_yudho_prasetyo@arch.its.ac.id
}

\begin{abstract}
Abstrak-Manusia hidup dalam sebuah lingkungan yang mampu mempengaruhi kondisi fisik maupun mental nya. Selain itu aktivitas yang dilakukan oleh manusia sehari - hari juga menjadi sebuah kunci utama kondisi tubuhnya. Sadar atau tidak sadar faktor eksternal mempengaruhi kondisi mental manusia itu sendiri. Kondisi mental manusia akan menghasilkan sebuaht respon yang salah satunya adalah emosi yang berkaitan erat dengan produktivitas. Keberadaan fenomena ini kemudian dijabarkan sebagai sebuah kemampuan pengguna dalam menterjemahkan ruangan yang ada disekitarnya. Yang kemudian dapat digambarkan sebagai Spatial Triad. Dengan adanya sebuah fenomena ini dapat dimanfaatkan untuk mengolah ruang yang ada pada sebuah tempat yang berhubungan dengan produktivitas. Oleh karena itu, sebuah perkantoran merupakan objek yang tepat sebagai wadah penerapan Spatial Triad yang kemudian menggunakan pendekatan desain Biophilic untuk penyelesaiannya.
\end{abstract}

Kata Kunci-Biophilic, Presepsi Ruang, Perkantoran Vertikal.

\section{PENDAHULUAN}

$\mathrm{M}$ ANUSIA hidup dalam sebuah lingkungan yang mampu mempengaruhi kondisi fisik maupun mental nya. Selain itu aktivitas yang dilakukan oleh manusia sehari - hari juga menjadi sebuah kunci utama kondisi tubuhnya. Sadar atau tidak sadar faktor eksternal mempengaruhi kondisi mental manusia itu sendiri. Kondisi mental manusia akan menghasilkan sebuah respon fenoma [1] yang disebut respon yang salah satunya adalah emosi yang berkaitan erat dengan produktivitas. Pada masa ini, kita hidup pada sebuah titik dimana fenomena yang sebelumnya diabaikan yaitu, emosi harus dipelajari dan dimanfaatkan (Picard, 1997). Emosi adalah perasaan intens yang ditujukan kepada seseorang atau sesuatu. Emosi adalah reaksi terhadap seseorang atau kejadian. Emosi memberikan kita kemampuan untuk membuat penilaian hampir disetiap situasi. Hal ini memungkinkan kita untuk menentukan tindakan yang berpengaruh kepada aktivitas yang sedang dijalanani. Pemicu munculnya emosi dapat berasal dari faktor eksternal maupun internal. Faktor internal tersebut seperti kondisi badan, hormonal dan sebagainya. Kemudian, untuk faktor eksternal itu sendiri berasal dari lingkungan disekitar manusia tersebut. Space salah satunya. Peran penting dari space ini sangat berpengaruh bagi emosi itu sendiri, sadar atau tidak sadar space mampu memberikan dampak kepada kondisi emosional manusia yang berada di dalamnya. Oleh karena itu munculah sebuah fenomena mengenai keterkaitan antara space dan respon manusia
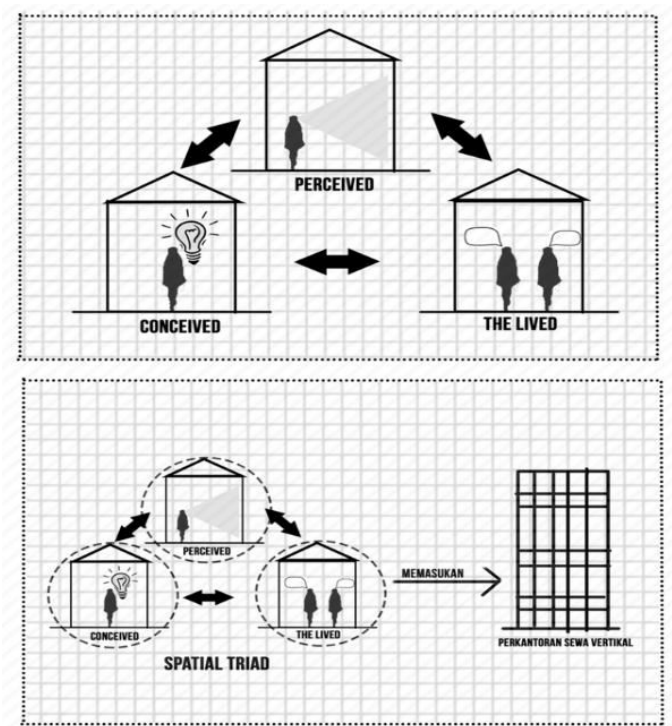

Gambar 1. Diagram Penerapan Spatial Triad.

Space yang hadir disekitar kita tidak dapat dipungkiri mampu mempengaruhi kondisi mental kita. Hal ini disebakan oleh presepsi yang kita hadirkan dalam memandang space itu sendiri. Pada dasarnya, space mempunyai peranan yang besar dalam menentukan produktivitas maupun emosi yang ada dalam diri kita.

Space pada awalnya merupakan konsep dari sebuah order atau susunan kemudian muncul pemahaman mengenai science of space (invented spaces; an infinity). Teori yang paling baru merupakan teori The modern Field of Epistemology atau space merupakan sebuah "mental thing" (ideological spaces) [2]. Sayangnya, space tidak berbicara bahasa manusia. Oleh karena itu untuk menghadirkan sebuah space yang mampu dimengerti oleh manusia, maka harus menggunakan bahasa tertentu untuk menghubungkan antara space dan manusia [3]. Sehingga perlu adanya sebuah teori tentang bagaimana menghadirkan space yang mampu dimengerti oleh manusia yang nantinya mampu menghasilkan sebuah emosi. Dalam sebuah buku mengenai "the production of space", Henri Lefebvre mengemukakan bahwa sebuah space terdiri dari beberapa level yang berbeda.

Space yang paling abstrak, natural space (absolute space) hingga space yang paling kompleks yang merupakan produk sosial atau dalam level ini disebut sebagai social space. Konsep space yang dihadirkan oleh Henri Lefebre merupakan konsep gabungan dari fisik, mental dan sosial. Space bukan merupakan sebuah benda, melainkan sebuah relasi anatara objek dan produk materialnya. Relasi antar keduanya ini 
mampu menyebabkan sebuah pergeseran emosi dan personal. Pergeseran level emosi dan personal ini menimbulkan Spatial Triad. Konsep spatial triad terdiri dari Spatial Practice, Representation of Space, dan Representational of space [4].

\section{METODE DESAIN}

\section{A. Programmatic Tools}

Dengan memasukkan kebutuhan ruang (program ruang) kedalam sebuah grid 10x10 (untuk menyederhanakan luasan). Program ruang yang dibutuhkan diurai menjadi 3 bagian yaitu 69 sel perkantoran, 7 sel area servis dan 14 sel area hijau berdasarkan dari perbandingan luasan area setiap lantai. Pada area grid 10x10 setiap program ruang disisipkan dan menjadi satu buah modul lantai.

\section{B. Conceptual Tools}

Setelah mendapatkan modul dari programmatic tools, memasukkan konsep utama dengan menata setiap area mampu mengakses area hijau secara visual maupun fisik. Sehingga dihasilkan 5 modul lantai yang kemudian diolah selanjutnya dengan formal tools.

\section{Formal Tools}

Untuk mencapai sebuah bentukan yang tepat maka dibutuhkan formal tools. Dimulai dari menentukan letak struktur, dengan menggunakan grid baru berukuran 10x10 dengan setiap kotaknya berukturan $1.2 \mathrm{~m}$ (standar berdasarkan lebar manusia). Setiap jarak $1.2 \mathrm{~m}$ merupakan titik kolom dan balok. Sehingga dengan sudah membuat grid struktur, modul dari hasil conceptual tools dimasukkan dan diolah kembali menyesuaikan grid struktur.
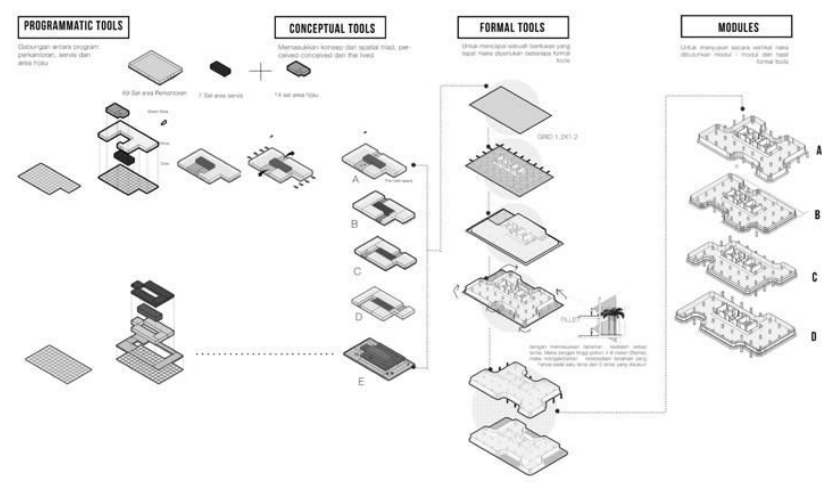

Gambar 2. Diagram Metode.

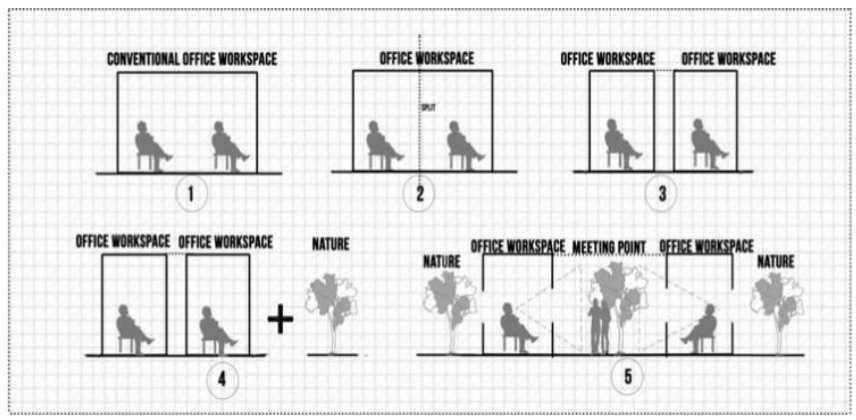

Gambar 3. Diagram Penerapan dan Konsep.
Perkantoran vertikal pada umunya merupakan perkantoran dengan konsep open office [1]. Ruang dari perkantoran tersebut kemudian dipisahkan menjadi beberapa bagian [2]. Celah antar ruang yang terjadi akibat pemecahan dari beberapa ruang perkantoran terbentuk [3]. Ruang perkantoran yang terpisah kemudian dimasukkan pendekan biophilic yaitu nature of space yang memasukan keberadaan alam [4]. Pengolahan lebih lanjut yaitu dengan menata masa dari ruang kerja tersebut sehingga memungkinkan visual langsung terhadap nature in space atau keberadaan alam di dalam bangunan [5].
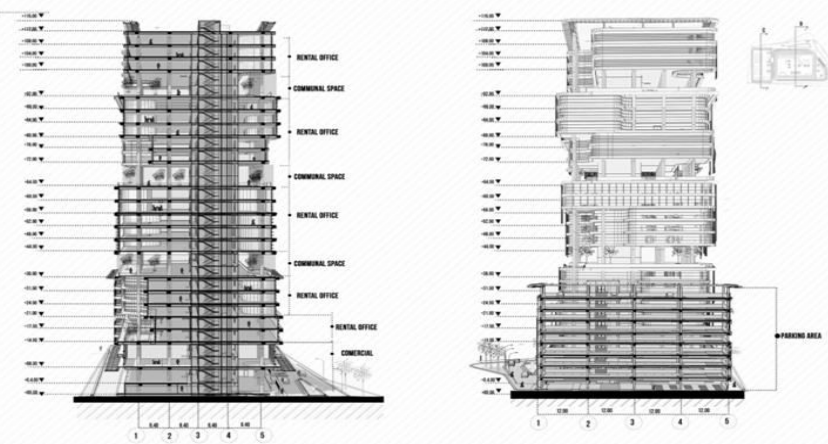

Gambar 4. Potongan.

\section{HASIL DAN EKSPLORASI}

Dengan pembahasan sebelumbya, sebuah spatial trial menjadi sebuah konsep utama dari perancangan perkantoran vertica dengan pendekatan Biophilic. Biophilic atau Biophilia adalah ilmu yang mempelajari keinginan manusia untuk berafiliasi dengan bentuk alam dalam kehidupan. Istilah 'biophilia' pertama kali diciptakan oleh psikolog sosial Eric Fromm dan kemudian dipopulerkan oleh ahli biologi Edward Wilson (Biophilia,1984). Istilah ini berkembang dari bidang biologi dan psikologi dan disesuaikan dengan berbagai bidang salah satunya bidang Arsitektur. Biophilia merupakan sebuah keinginan untuk berhubungan kembali dengan sebuah sistem alam atau (re) koneksi dengan alam dan sistem alam. Dalam arsitektur hal ini dikenal dengan desain biophilik atau hal ini adalah pengembangan biophilia dalam bidang desain ramah lingkungan, menyediakan kesempatan bagi manusia untuk memiliki hubungan dengan alam.

Dengan munculnya sebuah teori biophilia ini, pada tahun 1990-an, munculah berbagai penelitaian mengenai hubungan antara peningkatan kualitas lingkungan dan produktivitas pekerta. Produktivitas diidentifikasikan sebagai tempat untuk kesehatan dan kesejahteraan, yang memiliki dampak yang lebih luas.

Alam yang dimaksud dalam teori biophilic desain dibagi menjadi dua hal, yaitu sebuah konotasi dari alam tersebut dan alam adalah organisme hidup dan komponen non-hidup ekosistem (seperti matahari, air, dan sebagainya). Desain Biophilic sendiri dapat diatur ke dalam tiga kategori. Alam di Space (Nature in Space), Analogi dari Alam (Analogues of Nature), dan Nature of Space [5] untuk dapat menyediakan startegi desain. Oleh karena itu, konsep dari spatial triad akan di terapkan sebagai berikut: 


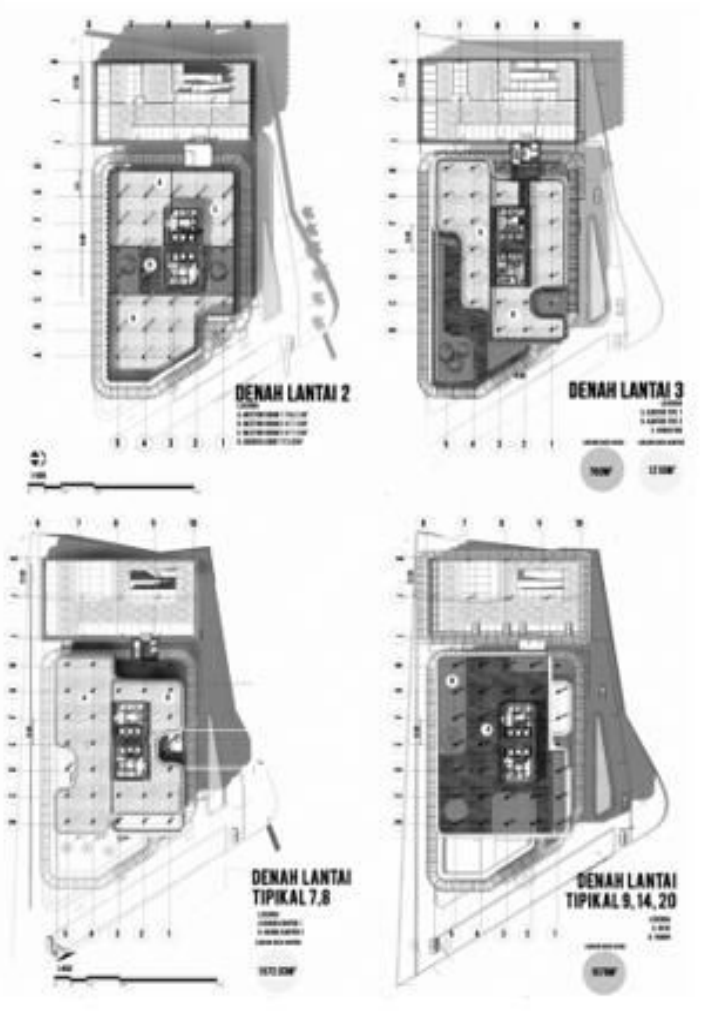

Gambar 5. Gambar denah.

a) Objek arsitektural mampu mempengaruhi perceived penggunanya secara visual dengan mengolah program ruang dimana minimal satu sisinya mendapatkan akses secara visual.

b) Objek arsitektural mampu memanfaatkan the lived space untuk memicu presepsi terhadap ruang dengan mengolah sirkulasi dalam perkantoran sehingga mampu menimbulkan interaksi untuk dapat berbincang mengenai apa yang pengguna rasakan dan terima dari lingkungan ruangannya.

c) Objek arsitektural mampu menunjang kebutuhan kebutuhan lain yang diperlukan dalam melengkapi objek arsitektural tersebut

\section{A. Sirkulasi}

Area sirkulasi menjadi titik poin penting dalam sebuah the lived space, dimana kemampuan sirkulasi untuk dapat mempertemukan pengguna sebanyak - banyak nya berbanding lurus dengan the lived space yang akan ada. Oleh karena itu, sirkulasi yang akan digunakan adalah berupa loop yang menghubungkan secara vertikal dan horizontal. S

Sirkulasi ini akan memanfaatkan area hijau yang ditempatkan pada setiap lantai untuk memaksimalkan fungsi ruang hijau dari bangunan tersebut.

Lantai dasar merupakan pusat dari sirkulasi masuk dan keluar kendaraan, kemudian pada lantai 1 dan 2 dipusatkan menjadi area khusus komersil atau disebut juga podium. Pada lantai 3 - 23 merupakan area perkantoran yang dipersewakan dan diselipkan area hijau pada lantai 14, 17 dan 20

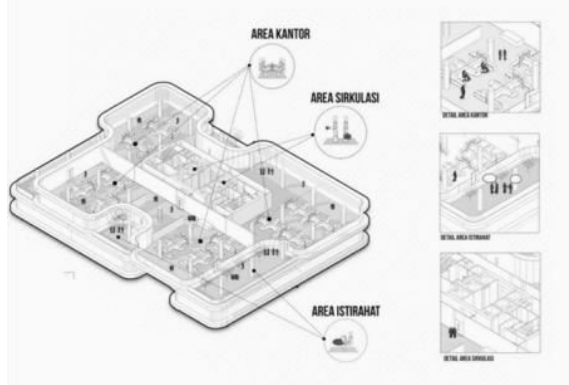

Gambar 6. Diagram Aktivitas.

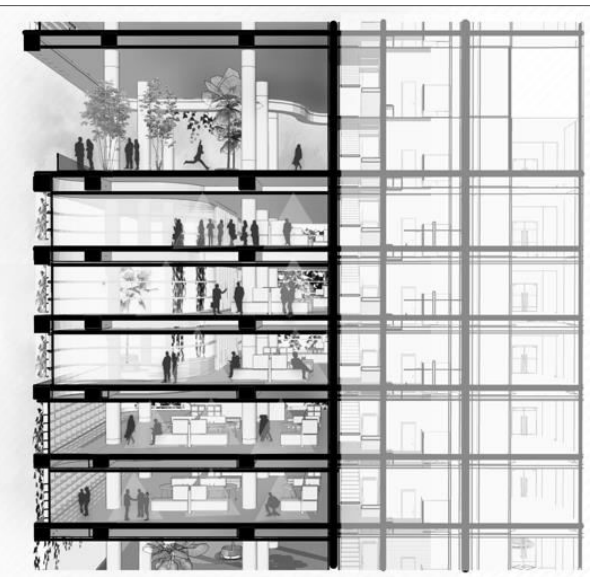

Gambar 7. Potongan Suasana.

\section{B. Rental office dan podium}

Podium merupakan sebuah area yang biasanya terletak pada bagian bawah dari bangunan tinggi yang isinya terdiri dari berbagai program ruang yang menunjang bangunan tinggi tersebut.

Pada area ini setiap ruangan ditata agar memiliki akses visual maupun fisik ke area penghijauan yang kemudian penataan ini akan dibahas pada penerapan metode. Ruang yang memiliki arah hadap ke area hijau merupakan bentuk

dari konsep perceived space dan kemampuan area hijau untuk dapat dijadikan area untuk akses secara fisik merupakan perwujudan dari conceived space. Sehingga penempatan dari area di setiap lantai dapat dimanfaatkan untuk menciptakan perceived dan the lived space

\section{KESIMPULAN/RINGKASAN}

Perancangan perkantoran vertikal ini merupakan bentuk implementasi dari konsep spatial triad dengan menggunakan pendekatan biophilic. Perancangan ini bertujuan untuk mempengaruhi tingkat produktivitas dari pengguna perkantoran. Pendekatan biophilic yang diambil adalah keberadaan alam pada sebuah ruang. Dimana akses visual maupun fisik dari pengguna sangat dipertimbangkan. Keberadaan alam yang dimasukkan kedalpam bangunan merupakan unsur yang disisipkan di sebuah bangunan perkantoran vertikal maka perlu penyusunan dalam perancangannya. Penataan dari keberadaan unsur unsur utama yaitu perkantoran dan alam perlu menjadi perhatian khusus. Karena itu, metode yang diambil merupakan metode grid untuk memudahkan penataan. 


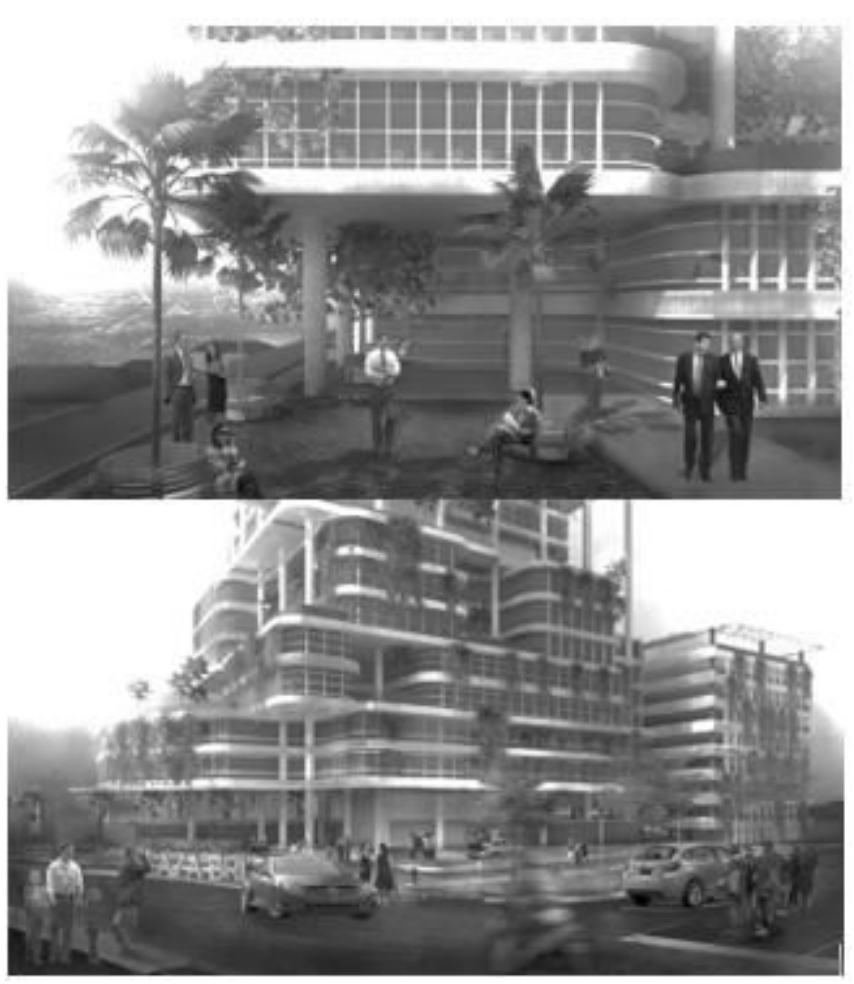

Gambar 8. Perspektif.

Gubahan massa yang ada merupakan konsekuensi dari penataan antara kedua unsur tersebut. Yang kemudian memperhatikan jarak pandang dan aksesibilitas dari penggunanya. Selain itu, fasad atau tampak dari bangunan merupakan konsekuensi dari arah datang matahari untuk meminimalisir cahaya matahari yang berlebihan terutama pada area barat dan selatan.

Untuk menerapkan konsep spatial triad dengan pendekatan biophiic ini perlu memperhatikan aspek aspek lingkungan dan pengguna sehingga tingkat produktivitas dapat terpengaruhi. Dengan menerapkan pendekatan biophilic yang merupakan sebuah ilmu yang sudah teruji sebelumnya, maka perancangan

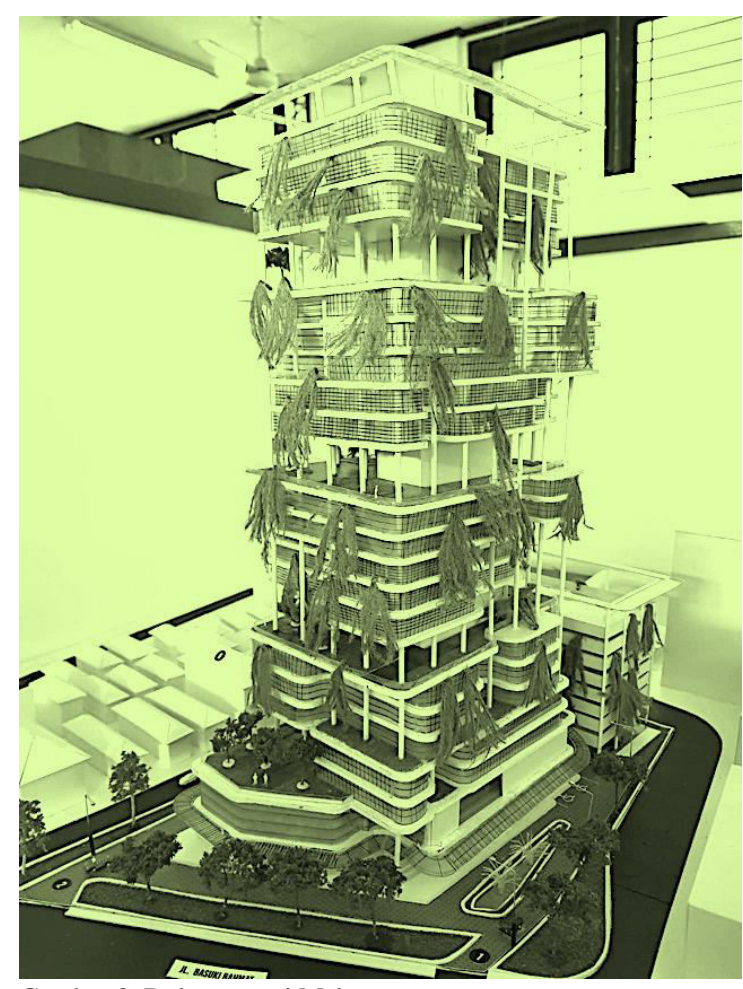

Gambar 9. Dokumentasi Maket.

ini mampu mempengaruhi tingkat produktivitas penggunanya.

\section{DAFTAR PUSTAKA}

[1] S. Holl and J. Palasmaa, Question of Perception: Phenomenology of Architecture. United States: William K Stout Pub, 2007.

[2] S. Kellert and E. Calabrese, The Practice of Biophilic Design. 2015.

[3] B. Lawson, The Language of Space. Oxford: Architectural Pres, 2001.

[4] H. Lefebrve, Production of Space. Oxford: Blackwell Publishing Ltd, 1974.

[5] R. Chaterine, "Emerging Nature - Based Parameters for Health and Well Being in the Built Environment," 2014. 